\title{
BLASTOCYST SURVIVAL AND NIDATION IN RATS TREATED WITH OESTROGEN ANTAGONISTS
}

\author{
GORDON W. DUNGAN AND ADELBERT D. FORBES \\ Biochemical Research, The Upjohn Company, Kalamazoo, Michigan, U.S.A. \\ (Received 6th October 1964, revised 15th April 1965)
}

Summary. U-11,100A and U-11,555A prevent pregnancy in rats when administered prior to the expected time of blastocyst implantation. When given to Provera-treated rats at effective antifertility doses, they do not interfere with survival of the blastocysts, with subsequent oestrone induced implantation or with the capacity of blastocysts to implant in new hosts.

Implantation is delayed in Provera-treated rats until such time as an oestrogen, such as oestrone, is administered. At pregnancy inhibiting doses, neither U-11,100A nor U-11,555A are capable of inducing implantation in the Provera-treated rat. When administered concomitantly with oestrone they can, however, prevent the expected oestrogen-induced implantation. In fact the combinations of U-11,555A and oestrone compatible with further embryonic development are very restricted. The nidatory process is more sensitive to changes in this balance than are the normal ovarian or vaginal functions associated with the oestrous cycle. The antifertility efficacy of these agents is ascribed to an alteration of oestrogen-sensitive implantation processes rather than to changes in tubal transport or to a direct effect on the blastocyst.

\section{INTRODUCTION}

Pre-implantation survival of blastocysts and nidatory mechanisms have been reviewed on a number of occasions recently (Blandau, 1961; Enders, 1963; Eckstein, 1959; Amoroso \& Finn, 1962). The complexity of the processes involved precludes even a summary description at this time. The present report, concerning effects observed with U-11,100A, a dihydronaphthalene and U-11,555A, a diphenylindene, ${ }^{*}$ are considered pertinent to this phase of mammalian development because of the capacity of these compounds to inhibit pregnancy when administered prior to the termination of the nidatory process.

Antifertility activity of these compounds in several species of laboratory animals-namely, mice, rats, guinea-pigs and rabbits-has previously been reported (Duncan, Stucki, Lyster \& Lednicer, 1962; Duncan, Lyster, Clark \& Lednicer, 1963). More recently antifertility effects have also been observed in

* U-11,100A = 1-\{2-[p-(3,4-dihydro-6-methoxy-2 - phenyl-1 -naphthyl)phenoxy]ethyl $\}$-pyrrolidine hydrochloride; U-11,555A $=2$-[p-(6-methoxy-2-phenylinden-3-yl)-phenoxy]-triethylamine hydrochloride (Lednicer, Babcock, Lyster, Stucki \& Duncan, 1961; Lednicer, Babcock, Lyster \& Duncan, 1963). 
laboratory primates. Of these various species, the rat was selected as the animal of choice for further examination of the biological profiles of $\mathrm{U}-11,100 \mathrm{~A}$ and U-11,555A.

Although differing substantially in potency, qualitative effects of both compounds on reproductive parameters were comparable. Antifertility efficacy was restricted to the period associated with the pre-implantation development of fertilized ova. Daily oral administration throughout this period or on any one of the 4 days following mating effectively inhibited pregnancy. Comparable doses or reasonable multiples of these doses administered on the fifth or subsequent days following mating were ineffective. Studies undertaken to relate the observed efficacy of these compounds to a physiologic parameter are the subject of this paper.

\section{MATERIALS AND METHODS}

Sprague-Dawley rats were used. They were maintained on Purina Laboratory Chow and tap-water ad libitum, and kept in an environment maintained at $78 \pm 2^{\circ} \mathrm{F}$ with $14 \mathrm{hr}$ of artificial light daily. Intact females weighing 200 to $250 \mathrm{~g}$ were caged overnight with males of established fertility. Presence of spermatozoa in vaginal smears the following morning established Day 1 of the experiment and, presumably, of pregnancy.

\section{Delayed implantation}

All females were treated with $1.5 \mathrm{mg}$ of 6a-methyl-17-acetoxy progesterone (Provera*) from Day 1 until the termination of the experiment to induce a delay in nidation and to facilitate the retention of un-implanted blastocysts in the uterus for prolonged periods of time. U-11,100A, U-11,555A and oestrone were administered according to various regimes during the Provera treatment. Both steroids were administered subcutaneously in sesame oil containing $5 \%$ benzyl alcohol. U-11,100A and U-11,555A were administered orally as suspensions in sterile water containing $0.25 \%$ methyl cellulose. At autopsy gross observations of implantation sites or foetuses were made or the oviducts or uterine cornua were flushed with rat plasma in an attempt to recover fertilized ova or non-implanted blastocysts.

\section{Transfer of blastocyst}

Blastocysts were recovered from uterine cornua on either Day 5 or Day 10 by flushing individual cornua with rat plasma. Groups of five to six blastocysts (judged to be normal when examined under a dissecting microscope $\times 32$ to 80 ) were introduced via a dorsal abdominal incision into the anterior end of the uterine cornua of the recipient female by means of a $10 \mu \mathrm{l}$ Hamilton microsyringe. The volume of plasma used for the transfer did not exceed $3 \mu \mathrm{l}$. All the transfers were made into pseudopregnant females on the 5th day following a sterile mating and the animals were killed either on Day 21 or at parturition. Clean, but not sterile, techniques were used throughout.

Donor rats received Provera and/or U-11,100A from Day 1 to the time of transfer. Provera was administered subcutaneously at a daily dose of $1.5 \mathrm{mg}$; $\mathrm{U}-11,100 \mathrm{~A}$ was administered orally at either 5 or $10 \mu \mathrm{g}$ daily.

\footnotetext{
* Registered trademark, The Upjohn Company.
} 


\section{RESULTS}

Daily oral administration of U-11,100A at doses of 5 and $25 \mu \mathrm{g}$ (equivalent to one and five times the minimal $100 \%$ effective antifertility dose) did not prevent the recovery of intact ova or blastocysts from the uteri of Proveratreated rats (Table 1). The administration of the compound was initiated at the time of mating and was continued daily for periods of up to 10 days after mating. The number of blastocysts recovered from each rat and the proportion of animals in which blastocysts were observed were comparable to those from

TABLE 1

OVA AND BLASTOCYST RECOVERY IN PROVERA-TREATED RATS SUBJECTED TO U-11,100A

\begin{tabular}{|c|c|c|c|c|c|c|c|}
\hline \multirow{2}{*}{$\begin{array}{c}\text { Oral dose of } \\
U-11,100 A \\
(\mu g / d a y, \\
\text { Day } 1 \text { to } \\
\text { autopsy) }\end{array}$} & \multicolumn{7}{|c|}{ Day of attempted recovery } \\
\hline & 1 & 2 & 3 & 4 & 6 & 8 & 10 \\
\hline $\begin{array}{r}0 \cdot 0 \\
5 \cdot 0 \\
25 \cdot 0\end{array}$ & $\begin{array}{r}10 \cdot 8 / 6 / 6 \\
7 \cdot 8 / 6 / 7\end{array}$ & $\begin{array}{l}7 \cdot 3 / 7 / 7 \\
5 \cdot 2 / 5 / 5\end{array}$ & $\begin{array}{l}4 \cdot 7 / 6 / 6 \\
4 \cdot 3 / 7 / 7\end{array}$ & $\begin{array}{l}3 \cdot 0 / 2 / 3 \\
5 \cdot 9 / 7 / 9\end{array}$ & $\begin{array}{l}7 \cdot 0 / 3 / 3 * \\
6 \cdot 0 / 3 / 3 \\
5 \cdot 0 / 2 / 3\end{array}$ & $\begin{array}{l}4 \cdot 5 / 2 / 3 \\
8 \cdot 0 / 1 / 2 \\
8 \cdot 3 / 3 / 3\end{array}$ & $\begin{array}{l}6 \cdot 5 / 2 / 5 \\
6 \cdot 2 / 4 / 4\end{array}$ \\
\hline
\end{tabular}

* Average no. ova or blastocysts/no. rats from which blastocysts were recovered/no. rats treated. Days 1 to 4, oviduct was flushed; Day 6, 8 and 10, uterus was flushed. Day 1 is day spermatozoa were observed in vaginal smear.

TABLE 2

OESTRONE-INDUCED IMPLANTATION IN PROVERA-TREATED RATS REGEIVING $\mathrm{U}-11,555 \mathrm{~A}$

\begin{tabular}{c|c|c|c}
\hline \multicolumn{2}{c|}{ Days of administration } & $\begin{array}{c}\text { No. rats with } \\
\text { implants } * / \\
\text { No. rats treated }\end{array}$ & $\begin{array}{c}\text { Average no. } \\
\text { implants or } \\
\text { blastocysts }\end{array}$ \\
\hline \begin{tabular}{c|c} 
U-11,555A \\
$0.1 \mathrm{mg}$ oral/day
\end{tabular} & $\begin{array}{c}\text { Oestrone } \\
1 \cdot 0 \mathrm{\mu} \mathrm{subq./day}\end{array}$ & $0 / 4$ & $7 \cdot 5$ \\
None & None & $7 / 8$ & $7 \cdot 4$ \\
None & $6-12$ & $8 / 8$ & $7 \cdot 1$ \\
$1-6$ & $6-12$ & $7 / 7$ & $8 \cdot 1$ \\
$8-15$ & $15-25$ & $0 / 7$ & $8 \cdot 1$ \\
$8-15$ & None & & \\
\hline
\end{tabular}

* Determined at autopsy on last day of oestrone treatment or on Day 15 for rats which did not receive oestrone. Day 1 is day spermatozoa were observed in vaginal smear.

Provera-treated controls. Blastocysts, subjected to U-11,100A during the period of transport through the oviduct or in utero, remained intact, and as revealed by the dissecting microscope did not appear to show degenerative changes (Plate 1).

The viability of such surviving blastocysts was suggested initially by the development of implantation sites in Provera-treated rats receiving U-11,555A but which were subsequently treated with oestrone (Table 2). Implantation was induced by administration of $1 \mu \mathrm{g}$ of oestrone, daily, to each of eight rats treated with U-11,555A for 6 days immediately after mating and to each of seven rats treated with U-11,555A for 8 days after the blastocysts had reached 
the uterus. The amount of U-11,555A used was equivalent to the minimal $100 \%$ effective antifertility dose. In the absence of oestrone, only non-implanted blastocysts were flushed from the uteri of each of seven rats receiving U-11,555A for 8 days.

Further evidence of blastocyst viability was obtained by utilizing the transfer of blastocysts from donors to non-treated pseudopregnant recipient rats. Six of eight recipients receiving 5-day blastocysts from vehicle-treated donor rats were pregnant (Table 3). Similarly, 5- and 10-day-old blastocysts were successfully transferred from Provera-treated mothers to 5-day pseudopregnant recipients. Supplementing the Provera treatment with either 5 or $10 \mu \mathrm{g}$ of U-11,100A did not prevent implantation and subsequent development of the transferred blastocysts. In the absence of Provera, blastocysts from U-11,100A-

TABLE 3

DEVELOPMENT OF RAT BLASTOCYSTS TRANSFERRED TO DAY 5 REGIPIENTS

\begin{tabular}{|c|c|c|c|c|}
\hline $\begin{array}{l}\text { Treatment of donor } \\
(\text { Day } 1 \text { to day of } \\
\text { transfer })^{*}\end{array}$ & $\begin{array}{l}\text { Donor day } \\
\text { of transfer }\end{array}$ & $\begin{array}{l}\text { Proportion of } \\
\text { rats pregnant } \dagger\end{array}$ & $\begin{array}{c}\text { Term foetuses as } \\
\text { proportion of } \\
\text { transferred } \\
\text { blastocysts }\end{array}$ & $\begin{array}{c}\text { Blastocysts } \\
\text { developed in } \\
\text { pregnant rats } \\
(\%)\end{array}$ \\
\hline $0.5 \mathrm{ml}$ vehicle, oral & 5 & $6 / 8$ & $18 / 48$ & 50 \\
\hline $1.5 \mathrm{mg}$ Provera & $\begin{array}{r}5 \\
10\end{array}$ & $\begin{array}{l}8 / 13 \\
7 / 9\end{array}$ & $\begin{array}{l}18 / 73 \\
23 / 70\end{array}$ & $\begin{array}{l}37 \\
40\end{array}$ \\
\hline $\begin{array}{l}1.5 \mathrm{mg} \text { Provera } \\
+5 \mathrm{\mu g} \mathrm{U}-11,100 \mathrm{~A}\end{array}$ & 5 & $8 / 8$ & $29 / 56$ & 52 \\
\hline $\begin{array}{l}\text { 1.5 mg Provera } \\
+10 \text { ug U- } 11,100 \mathrm{~A}\end{array}$ & 5 & $3 / 5$ & $4 / 36$ & 15 \\
\hline $5 \mu \mathrm{g} \mathrm{U}-11,100 \mathrm{~A}$ & 5 & $2 / 3$ & $8 / 25$ & 53 \\
\hline $10 \mu g \mathrm{U}-11,100 \mathrm{~A}$ & 5 & $5 / 6$ & $14 / 53$ & 34 \\
\hline
\end{tabular}

* Day 1 is day spermatozoa were observed in vaginal smear.

$\dagger$ Those rats with viable foetuses either at Day 21 or at parturition.

treated mothers were successfully transferred on Day 5 of pregnancy. Transfer of blastocysts at Day 10 of pregnancy from rats receiving only U-11,100A was not attempted because of the failure to recover any blastocysts.

The possibility that an antagonism to the oestrogen-induced implantation might result from concomitant indene or dihydronaphthalene administration was evaluated by using Provera-treated rats in which delayed implantation had been induced. Oral administration of U-11,555A was initiated at the time of mating and continued for 6 days. With a daily dose of $0.1 \mathrm{mg}$, implantation (as determined at autopsy on Day 12) was induced in six of nine rats when this treatment was followed by $1 \mu \mathrm{g}$ of oestrone daily (Table 4). Raising the dose of U-11,555A to $0.5 \mathrm{mg}$ or initiating the concomitant administration of oestrone at the time of breeding or during tubal transport either inhibited or completely prevented implantation. Oestrone treatment in the absence of U-11,555A was, however, compatible with blastocyst implantation 
PLATE 1

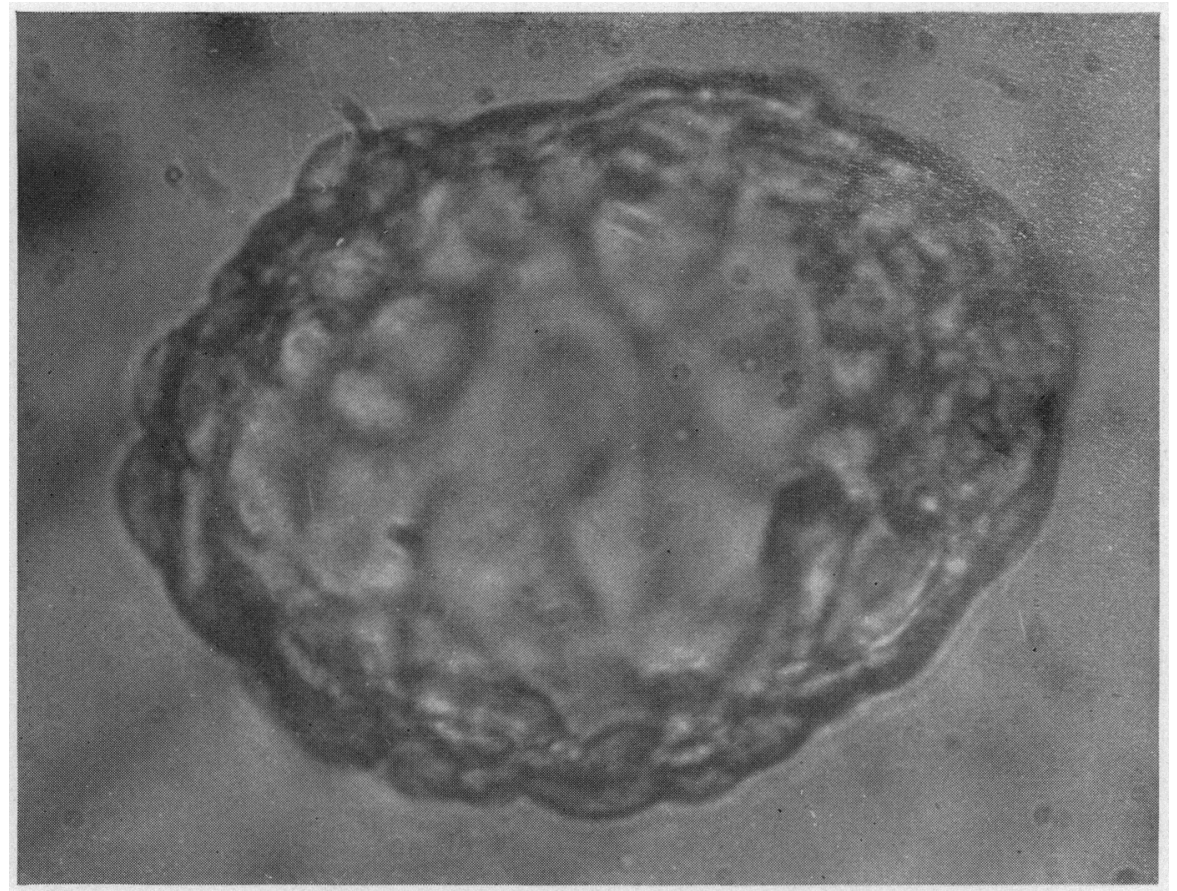

Typical blastocyst flushed from the uterus on Day 8 of a Provera-treated rat subjected to daily treatment from Day 1 to 8 with $\mathrm{U}-11,100 \mathrm{~A}$.

(Facing p. 164) 
whether initiated on Day 1, 3 or 6 of pregnancy. The most favourable combination of $\mathrm{U}-11,555 \mathrm{~A}$ and oestrone for blastocyst survival was $0.1 \mathrm{mg}$ of $\mathrm{U}-11,555 \mathrm{~A}$ from Day 1 to 6 followed by $1 \mu \mathrm{g}$ of oestrone daily. Using this same sequence of administration of the two substances, it was found that increasing the dose of either the indene or the oestrogen was not compatible with blastocyst survival (Table 4). Well-developed foetuses were observed with only two of the nine combinations when the rats were autopsied on Day 21.

TABLE 4

IMPLANTATION IN PROVERA-TREATED RATS SUBJECTED TO U-11,555A AND OESTRONE

\begin{tabular}{|c|c|c|c|}
\hline \multirow{2}{*}{$\begin{array}{l}\text { Daily dose of } U-11,555 A \\
(m g / \text { day-Day } 1 \text { to } 6)^{*}\end{array}$} & \multicolumn{3}{|c|}{ Day of oestrone treatment ( $1 \mu g$ daily) } \\
\hline & 1 to 12 & 3 to 12 & 6 to 12 \\
\hline $\begin{array}{l}0.0 \\
0 \cdot 1 \\
0.5\end{array}$ & $\begin{array}{l}10-9-6-5-5-1-0-0-0 \dagger \\
0-0-0-0-0-0-0-0-0 \\
0-0-0-0-0-0-0-0-0\end{array}$ & $\begin{array}{l}11-6-4-3-3-2-2-0-0 \\
4-3-2-0-0-0-0-0-0 \\
0-0-0-0-0-0-0-0-0\end{array}$ & $\begin{array}{l}14-13-12-12-11-6-4-1-0 \\
14-14-6-6-2-1-0-0-0 \\
0-0-0-0-0-0-0-0-0\end{array}$ \\
\hline \multirow{2}{*}{$\begin{array}{l}\text { Daily dose of } U-11,555 A \\
(m g / d a y-D a y 1 \text { to } 6)^{*}\end{array}$} & \multicolumn{3}{|c|}{ Daily dose of oestrone ( $\mu \mathrm{g} / \mathrm{day}-D a y$ 7-21) } \\
\hline & $0 \cdot 1$ & $1 \cdot 0$ & $5 \cdot 0$ \\
\hline $\begin{array}{l}0 \cdot 1 \\
0.5 \\
1 \cdot 0\end{array}$ & $\begin{array}{l}10-2-1-1-0 \\
0-0-0-0-0 \\
0-0-0-0-0\end{array}$ & $\begin{array}{l}7-3-3-2-1-0-0 \\
0-0-0-0 \\
0-0-0-0\end{array}$ & $\begin{array}{l}0-0-0-0 \\
0-0-0-0-0 \\
0-0-0-0-0\end{array}$ \\
\hline
\end{tabular}

* Day 1 is day spermatozoa were observed in vaginal smear.

$\dagger$ No. implantation sites/rat on last day of oestrone treatment.

\section{DISCUSSION}

U-11,100A and U-11,555A tested under conditions identical to those used in this study, completely inhibited pregnancy in rats at daily doses of 5 and $100 \mathrm{\mu g}$, respectively. The partial characterization of the pregnancy-inhibiting and other biological activities of both compounds has been published (Nelson, Davidson \& Wada, 1963; Duncan et al., 1962, 1963). The doses used in the present study were selected to evaluate these therapeutic levels.

In the light of reports that oestrogens and oestrogen antagonists inhibit development of fertilized ova (Chang, 1959; Jolley, Martin, Bamberger \& Stearns, 1962; Daniel, 1964), a direct inhibitory effect of U-11,100A and U-11,555A on the developing blastocyst must be considered. Provera-induced delayed implantation (Barnes \& Meyer, 1960, 1964) was used to extend the period during which blastocysts could be subjected to treatment. Administration of U-11,100A for periods up to 10 days following mating did not reduce the number of intact blastocysts recovered as compared with Provera-treated controls. Viability of the blastocysts, which were normal in gross appearance, was established by their subsequent development in both oestrogen-treated rats and in untreated recipients following blastocyst transfer.

Provera was administered in all of the delayed implantation studies. It does not appear that this progestin afforded the blastocyst protection against direct effects of the test compounds since blastocysts subjected to U-11,100A 
in the absence of Provera were also successfully transferred. The progestin treatment does, however, facilitate the retention of blastocysts in the uterus during treatment. Attempts to flush 10-day blastocysts from the uteri of pregnant rats which had received only $\mathrm{U}-11,100 \mathrm{~A}$ were unsuccessful, the blastocysts presumably having been lost through the cervical os. Chang (1964) reported abnormal oviduct transport and expulsion of ova from uteri of U-11,555Atreated rabbits. He attributed the observed degeneration of ova to alterations in pre-implantation transport mechanisms rather than to a direct effect of the compound on the blastocysts.

Rate of tubal transport is critical to embryonic development in the rat. In rats treated only with U-11,100A, oviduct transport is slightly accelerated, and 30 to $50 \%$ of the blastocysts are found in the uterus 12 to $24 \mathrm{hr}$ earlier than in controls (unpublished data). The extent of the curtailment of tubal transport time and the number of ova affected suggest this is not the prime mechanism involved in the antifertility effect.

These compounds do apparently antagonize implantation processes. Implantation responses during concomitant U-11,555A-oestrone administration to Provera-treated rats were suggestive of an oestrogen-antagonistic activity for the indene (Duncan \& Lyster, 1963). Jacobson, Smith, Colucci \& Jensen (1964) have shown that both U-11,100A and U-11,555A function as oestrogen antagonists in the uterus and vagina by preventing steroid retention in these organs. In exploring the implantation relationships, it is apparent that the level of oestrogen available at implantation is extremely critical. Increasing the titre of either oestrone or U-11,555A, or initiating oestrone treatment earlier, completely inhibited the nidatory response. Nutting \& Meyer (1963) reported similar oestrogen sensitivity in ovariectomized-progesterone treated rats. The minimal dose required to produce consistent nidation was between 0.3 and $3.0 \mathrm{\mu g}$ daily; a dose of $10 \mathrm{\mu g}$ resulted in more or less complete inhibition of implantation. In contrast, no doses of either U-11,100A or U-11,555A have yet been found which will induce implantation.

If the pregnancy inhibiting effect of U-11,100A and U-11,555A can be ascribed to an inhibition of implantation, the high relative sensitivity of the nidatory phase of reproduction to oestrogen titres is apparent from the lack of effect of either compound on other reproductive processes at doses which consistently inhibit pregnancy. In addition, these compounds, when administered at effective pregnancy-inhibiting levels for periods equivalent to twenty-four oestrous cycles, did not inhibit cyclic ovarian or vaginal changes, mating, pseudopregnancy or subsequent breeding and parturition. Variation in sensitivity of reproductive mechanisms to oestrogen titres within and between species and the enlarged spectrum of biological activities observed in studies using higher doses of U-11,100A or U-11,555A suggest that other factors may be involved in the antifertility efficacy under conditions differing from those reported here.

\section{ACKNOWLEDGMENTS}

The authors wish to thank Drs J. C. Babcock and D. Lednicer for supplies of $\mathrm{U}-11,100 \mathrm{~A}$ and U-11,555A. 


\section{REFERENCES}

Amoroso, E. C. \& FinN, C. A. (1962) Ovarian activity during gestation, ovum transport and implantation. The Ovary, Vol. I. Ed. S. Zuckerman. Academic Press, New York.

Barnes, L. E. \& MEYer, R. K. (1960) Induction of delayed implantation in intact rats by Provera (6-alpha-methyl-17-acetoxyprogesterone). Anat. Rec. 137, 337.

Barnes, L. E. \& MEYER, R. K. (1964) Delayed implantation in intact rats treated with medroxyprogesterone acetate. F. Reprod. Fertil. 7, 139.

Blandau, R. J. (1961) Biology of eggs and implantation. Sex and Internal Secretions, Vol. II, p. 797. Ed. W. C. Young. Williams \& Wilkins, Baltimore.

Ghang, M. G. (1959) Degeneration of ova in the rat and rabbit following oral administration of 1-(p-2-diethylaminoethoxyphenyl)-1-phenyl-2-p-anisylethanol. Endocrinologv, 65, 339.

Chang, M. C. (1964) Effects of certain antifertility agents on the development of rabbit ova. Fertil. Steril. $15,97$.

Daniel, J. C., Jr. (1964) Some effects of steroids on cleavage of rabbit eggs in vitro. Endocrinology, 75, 706.

Duncan, G. W. \& Lyster, S. C. (1963) Effect of a diphenylindene derivative (U-11,555A) on blastocyst survival in utero. Fertil. Steril. 14, 565.

Duncan, G. W., Lyster, S. C., Glark, J. J. \& Lednicer, D. (1963) Antifertility activities of two diphenyl-dihydronaphthalene derivatives. Proc. Soc. exp. Biol., N.Y. 112, 439.

Duncan, G. W., Stucki, J. C., Lyster, S. C. \& Lednicer, D. (1962) An orally effective mammalian antifertility agent. Proc. Soc. exp. Biol., N.Y. 109, 163.

Eckstein, P. (1959) Implantation of ova. Mem. Soc. Endocrin. No. 10. Cambridge University Press.

Enders, A. C. (1963) Delayed implantation. University of Chicago Press.

Jacobson, H. I., SmIrri, S., Colucci, V. \& JENSEN, E. V. (1964) Effect of anti-uterotropic agents on the uptake of estradiol by rat tissues. Endocrine Society Meeting, Abstract 31, San Francisco, California.

Jolley, W. B., Martin, W. E., Bamberger, J. W. \& Stearns, L. W. (1962) Effect of oestradiol-17 $\beta$ on cleavage, nucleic acid metabolism and protein synthesis in sea urchin, Strongylocentrotus purpuratus, embryos. F. Endocrin. 25, 183.

Lednicer, D., Babcock, J. C., Lyster, S. C. \& Duncan, G. W. (1963) Derivatives of 1,2-diphenyl-3,4dihydronaphthalene as antifertility agents. Chem. Ind., p. 408.

Lednicer, D., Babcock, J. C., Lyster, S. C., Stucki, J. G. \& Duncan, G. W. (1961) Derivatives of 2,3-diphenylidenes as antifertility agents. Chem. Ind., p. 408.

Nelson, W. O., Davidson, O. W. \& Wada, K. (1963) Studies on interference with zygote development and implantation. Delayed Implantation. Ed. A. C. Enders. University of Chicago Press.

NUTting, E. F. \& MEYER, R. K. (1963) Implantation delay, nidation and embryonal survival in rats treated with ovarian hormones. Delayed implantation. Ed. A. G. Enders. University of Chicago Press. 